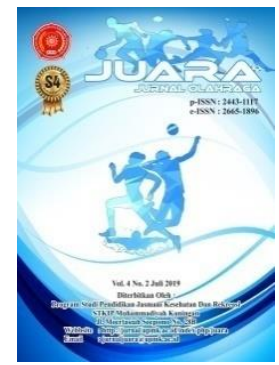

\title{
Korelasi Antara Kelincahan Dengan Topspin Tenis Meja Atlet Kota Kendari
}

\section{Correlation Between Agility and Athletes Topspin of Table Tennis in Kendari City}

Rahedin Suwo

Faculty of Teacher Training and Education, Universitas Sembilanbelas November Kolaka, Jl. Pemuda, Tahoa, Kolaka, Kabupaten Kolaka, Sulawesi Tenggara 93561, Indonesia

Email : rahedinsuwou76@gmail.com

\section{Info Artikel}

SejarahArtikel:

Diterima 27 Oktober 2019

Disetujui 25 Desember 2019

Dipublikasikan 29 Desember 2019

Keywords:

Agility, Topspin, Table

Tennis

\begin{abstract}
Abstrak
Penelitian ini bertujuan untuk mengetahui hubungan tentang kelincahan dengan peningkatan kemampuan topspin atlet tenis meja kota Kendari. Penelitian ini menggunakan pendekatan kuantitatif dengan teknik korelasional. Populasi dalam penelitian ini adalah seluruh atlet Kota Kendari yang berjumlah 62 orang tergabung dari 2 club yaitu PTM Maleo dan PTM UHO, dimana PTM Maleo berjumlah 32 orang yang terdiri dari 20 atlet putra dan 12 atlet putri. Sedangkan PTM UHO berjumlah 30 orang yang terdiri 16 putra dan 14 atlet putri. Sampel dalam penelitian ini diambil dengan menggunakan teknik purposive sampling yaitu dengan pertimbangan jenis kelamin putra, sehingga sampel dalam penelitian ini berjumlah 36 atlet putra. Untuk penilaian hasil analisis menggunakan uji korelasi. Hasil menunjukan bahwa terdapat korelasi kuat antara kelincahan dalam meningkatkan kemampuan topspin. Artinya, semakin lincah seorang atlet maka semakin tinggi kemampuan topspin. Oleh sebab itu, hubungan antara kelincahan dengan peningkatan kemampuan topspin atlet tenis meja kota kendari sangat berkaitan erat.
\end{abstract}

\begin{abstract}
This research aims to determine the relationship between agility and the increase of athletes' topspin ability of table tennis in Kendari City. This research used a quantitative approach and correlational technique. The population in this research were all athletes of Kendari City, amounting to 62 people from 2 clubs, namely PTM Maleo and PTM UHO, where PTM Maleo numbered 32 people consisting of 20 male athletes and 12 female athletes. While UHO PTM numbered 30 people consisting of 16 male and 14 female athletes. The sample in this research was taken using a purposive sampling technique that is with consideration of male, so the sample in this research amounted to 36 male athletes. To assess the results of the analysis using the correlation test. The results show that there is a strong correlation between agility in increasing table tennis topspin. That is, the more agile an athlete, the higher the ability of topspin. Therefore, the relationship between agility and increasing the
\end{abstract}




\section{ability of topspin athletes in Kendari City table tennis is very closely related.}

Alamat korespondensi: Jl. Pemuda, Tahoa, Kolaka, Kabupaten Kolaka, Sulawesi Tenggara 93561

E-mail: rahedinsuwou76@gmail.com

No Handphone : 082341186601

\section{PENDAHULUAN}

Setiap orang dalam menjalankan aktivitasnya tidak luput dari olah tubuh/ olahraga, olah rasa, dan olah pikir. Aktivitas fisik/ olahraga yaitu selalu sejalan pada kebugaran jasmani yang setiap kegiatannya berkelanjutan (Safaringga \& Herpandika, 2018). Sehingga masing-masing mempunyai tujuan sendiri dalam melakukan kegiatan olahraga baik yang bersifat rekreasi maupun prestasi.

Olahraga rekreasi yaitu salah satu jenis kegiatan pengganti hari kerja yang dilakukan pada hari libur. Biasanya aktivitas ini mampu menjadikan seseorang lebih segar yang berefek pada pemikiran dan tubuh. Sedangkan olahraga prestasi adalah pelaksanaan kegiatan yang memiliki satu arah yaitu kemenangan atau hadiah (Rahmani, 2014). Olahraga prestasi ini memiliki level dimulai dari internasional maupun nasional. Internasional terbagi pada kategori Olimpiade, ASEAN Games, SEA Games. Sedangkan tingkat nasional terbagi pada Kejurda, Porprov, Kejurnas dan PON.

Kemajuan prestasi tenis meja di Indonesia sangat cepat seiring kemajuan teknologi dan perkembangan zaman. Berdasarkan pengamatan dan wawancara beberapa pelatih ketika penulis menjadi pendamping kontingen Sultra diajang PON Bandung 2016, dapat dilihat daerah-daerah telah banyak klub-klub dan pemusatan latihan yang telah digalakkan. Hal ini guna pencapaian prestasi, salah satunya seperti daerah Jawa Barat, DKI Jakarta, Banten, Jawa Timur dan Sulawesi Tenggara. Tenis meja sangat berkembang pesat yang ditandai dengan adanya pertandingan yang diselenggarakan oleh pemerintah daerah dari kelompok umur kategori kadet, junior, yunior, senior maupun veteran setiap sebulan, triwulan dan setahun sekali. Untuk pencarian bakat dan kelompok umum mulai divisi 7 (pemula) sampai divisi 1 (pemain nasional).

Dalam permainan tenis meja tentu menggunakan raket/bet yang identik dengan gerakan intermiten, termasuk gerakan singkat diselingi dengan istirahat pendek (Zagatto, Kondric, Knechtle, Nikolaidis, \& Sperlich, 2018). Alat yang digunakan permainan ini memiliki banyak macam dan kriteria, tergantung pada kebutuhan dan kecocokan masing-masing player. Pada kayu (blade) ada yang berfungsi sebagai bertahan dan menyerang. Sedangkan karet (rubber) ada berjenis bintik untuk bertahan dan jenis polos untuk menyerang. Masing-masing alat tersebut memiliki keunggulan dan kelemahannya.

Permainan tenis meja selain memerlukan alat latihan dan tanding juga harus memiliki koordinasi, ketangkasan dan energi agar bermain dengan baik. Selain itu didukung oleh komponen kebugaran tubuh termasuk pergelangan tangan, lengan, perut, paha dan tungkai. Kemudian penguasaan teknik pukulan sangat penting yang didukung gerakan kecepatan kaki yang lincah karena berperan penting dalam permainan ini.

Namun beberapa kejuaraan daerah nampak banyak atlet pelajar, mahasiswa maupun daerah memiliki kekurangan dalam penguasaan teknik bermain tenis meja dan lambatnya gerakan dalam menghadapi serangan. Hal ini disebabkan oleh rendahnya penguasaan teknik serangan yaitu topspin sehingga perlu di teliti faktor apa yang 
mempengaruhi teknik tersebut. Kekurangan saat pergerakan topspin banyak dijumpai pada saat bola yang tidak mengenai bet dan tidak tepat sasaran (Suwo, 2019). Keunggulan dari penigkatan topspin adalah mudah mendapatkan poin/angka dimana pemain dapat mengembalikan bola dengan berbagai karakter jenis putaran (Akbar, 2015). Jadi, topspin merupakan bagian dari teknik permainan tenis meja dimana bola dipukul untuk menghasilkan putaran yang besar sehingga dengan rotasi bola akan membuatnya mengarah ke permukaan meja.

Pada daerah sulawesi tenggara masih banyak kita jumpai atlet dengan pukulan keras tetapi sangat lemah pada saat menjumpai bola yang berada pada posisi tengah tubuh sehingga bola lebih banyak jatuh mengenai net, keluar meja dan tidak dapat melakukan serangan. Hasil wawancara dengan pelatih salah satu klub tenis meja kota Kendari, hal ini diakibatkan oleh lambatnya pergerakan pada saat merespon datangnya bola atau lambat dalam mengambil kepeutusan. Sehingga peneliti tertarik untuk menggunakan faktor kelincahan pada peningkatan topspin tenis meja.
Faktor kelincahan dipengaruhi oleh adanya stimulus (bola) yang menjadikan seseorang mengambil sebuah keputusan untuk bergerak kearah tertentu dalam menanggapi sebuah ransangan (Paul, Gabbett, \& Nassis, 2016). Ketika lawan mengembalikan bola dengan berbagai jenis putaran, hal ini menjadi sebuah stimulus bagi seorang pemain untuk menentukan arah pergerakan yang tepat dengan menggunakan teknik serangan terbaik pada kondisi itu. Kelincahan dipengaruhi oleh pengubahan percepatan gerak yang berhubungan dengan teknik, kecepatan, otot lengan dan anthropometry (Sheppard \& Young, 2006). Olehnya itu, pergerakan yang lincah dikombinasikan teknik serangan dan pertahanan akan menentukan point bertambah terutama pada penggunaan teknik topspin. Serangan yang bertubi-tubi diarahkan kepada lawan yang didukung oleh kelincahan, menjadi serangan dan pertahanan terbaik dalam mematikan lawan untuk memperoleh angka. Proses terjadinya kelincahan secara rinci dalam permainan tenis meja disajikan dalam gambar berikut:

Gambar 1 urutan kelincahan pada cabang olahraga

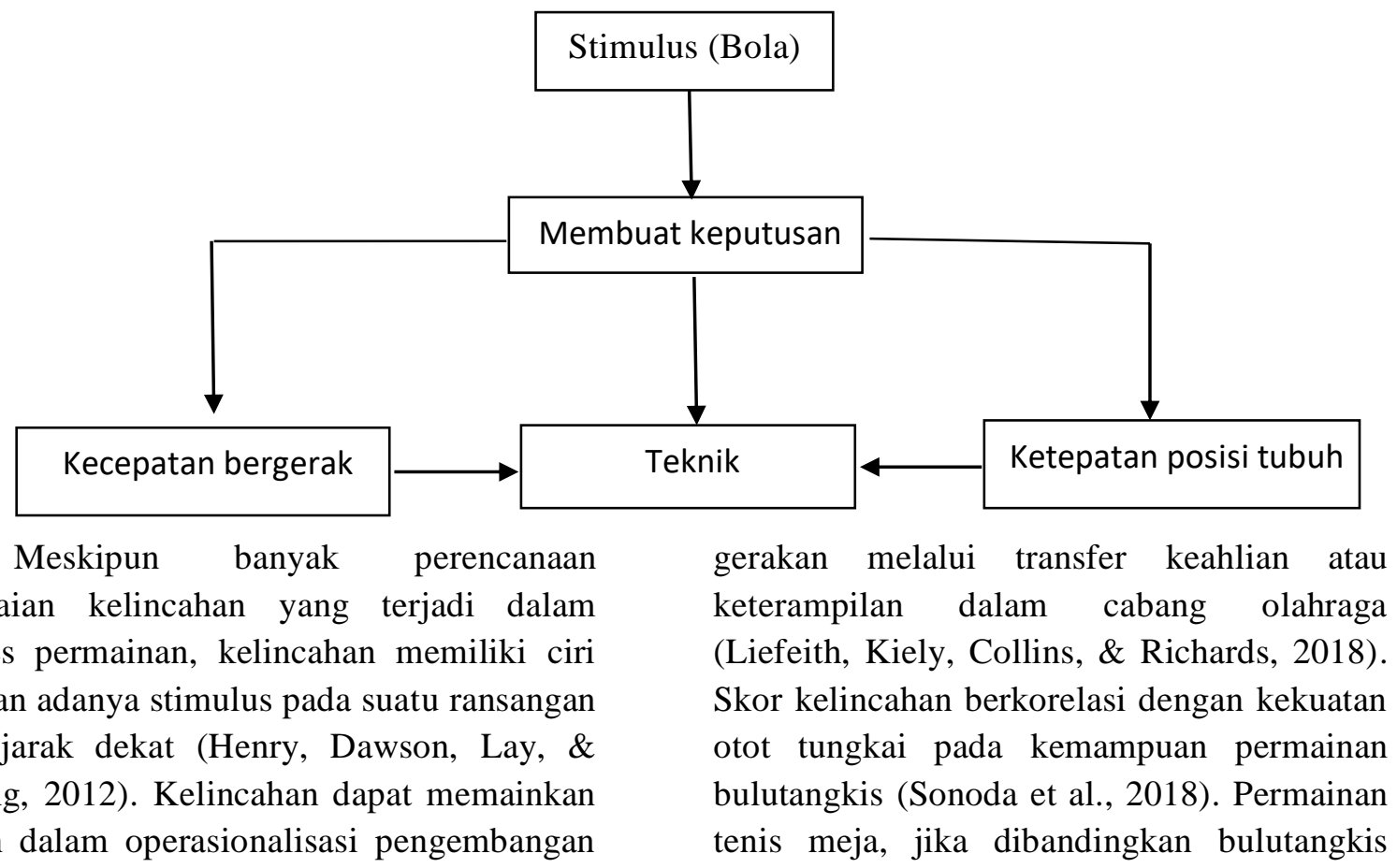


memiliki lapangan lebih kecil dengan putaran bola yang cepat. Kondisi ini menunjukan pada setiap pelaksanaan teknik permainan tenis meja, dimana bola yang datang keberbagai arah adalah stimulus. Setiap atlet dapat membuat sebuah keputusan untuk bergerak dengan cepat ke arah stimulus, terutama bola yang berada ditengah tubuh atau jauh dari posisi tubuh sehingga memerlukan perubahan posisi tubuh ke posisi yang mendekati arah stimulus dengan menggunakan teknik yang dapat mematikan pergerakan lawan untuk mendapatkan angka. Namun, sedikitnya penelitian untuk meneliti tentang faktor kelincahan terutama dalam permainan tenis meja menyebabkan penelitian ini harus terlaksana. Dengan terlaksananya penelitian ini, dapat dijadikan sebagai acuan oleh peneliti selanjutnya dalam koridor masalah yang sama.

Agility atau kelincahan adalah sejumlah kemampuan kompleks yang dimiliki oleh seseorang saat merespon dan perubahan arah (Lubis, 2013). Jika terdapat atlet dengan reaksi yang cukup akan tetapi tidak ditunjang oleh kemampuan kelincahan pergerakan, tentunya sulit untuk mengejar bola yang datang (Suwo, 2019). Selanjutnya penggunaan alat bantu latihan mampu meningkatkan pada atlet pemula saja, namun lemah pada atlet menengah ke atas (Santosa, 2016). Oleh karena itu, perlu digunakan unsur berbeda yaitu melalui korelasi antara kelincahan dengan peningkatan topspin. Sehingga keberadaan penelitian ini mampu menunjukan faktor kelincahan perlu ditingkatkan dan dipertahankan demi memaksimalkan kemampuan topspin setiap atlet.

Faktor-faktor yang mempengaruhi kelincahan yaitu: (1) komponen biomotor seperti kekuatan otot, speed, power otot, waktu reaksi, keseimbangan, dan koordinasi, (2) tipe tubuh, (3) umur, (4) jenis kelamin, (5) berat badan dan (6) kelelahan (Mylsidayu \& Kurniawan, 2015). Senada penelitian berikut bahwa unsur kelincahan memeberikan kontribusi yang kuat pada kemampuan menggiring bola basket (Sari, 2019).

Maksud dari penelitian ini untuk memastikan korelasi antara kelincahan dengan peningkatan topspin atlet tenis meja kota Kendari. Serupa dengan penelitian relevan mengungkapkan bahwa kemampuan reaksi tangan signifikan terhadap keterampilan forehand topspin (Suwo, 2019). Pada penelitian terdahulu juga memaparkan terdapat banyak masalah yang mempengaruhi topspin, diantaranya reaksi tangan, gizi, koordinasi mata-tangan, kelincahan, kecepatan, percaya diri dan lain-lain. Akhirnya dapat diapahami kekurangan penelitian terdahulu yaitu hanya menggunakan unsur reaksi tangan saja sehingga belum terjawab dari semua masalah yang ditemukan oleh peneliti sebelumnya.

Berdasarkan penelitian relevan di atas peneliti mencoba untuk menjawab masalahmasalah yang ditemukan dan menggunakan salah satu unsur yaitu kelincahan dengan peningkatan topspin atlet tenis meja kota Kendari. Untuk dapat diketahui perbedaannya penelitian ini dengan penelitian terdahulu adalah penelitian terdahulu menggunakan metode survey melalui pendekatan analisis jalur (path analysis). Sedangkan penelitian ini menggunakan pendekatan kuantitatif, dengan teknik korelasi. Penelitian ini merupakan kelanjutan dari penelitian terdahulu tentang berbagai masalah yang belum terjawab sehingga melalui penelitian ini mendapatkan jawaban yang signifikan. Hasil penelitian ini diharapkan mendapatkan hasil yang positif sehingga dapat menjadi tambahan wawasan dalam melatih atau membina salah satu cabang olahraga khususnya tentang peningkatan kemampuan topspin.

Mengamati keunggulan dan kelemahan masing-masing unsur, penelitian ini bermaksud untuk mengetahui seberapa besar kontribusi kelincahan dengan peningkatan 
kemampuan topspin atlet tenis meja kota Kendari.

\section{METODE PENELITIAN}

Penelitian ini merupakan jenis penelitian deskriptif. Desain penelitian ini yaitu korelasional dengan menghubungkan kelincahan dengan topspin atlet tenis meja. Data kelincahan diperoleh melalui tes Agility T-Test. Sedangkan kemampuan forehand topspin diperoleh dengan menggunakan tes return board. Populasi dalam penelitian ini adalah seluruh atlet tenis meja kota Kendari yang tergabung dari dua club tenis meja yaitu PTM Maleo dan PTM UHO berjumlah 62 atlet. Sedangkan sampelnya dengan jumlah 36 atlet. Teknik memilih sampel dari populasi yang tersedia yaitu dengan menggunakan teknik purposive sampling atau melalui pertimbangan berjenis kelamin putra, dimana peneliti tidak mencampur sampel penelitian putra dan putri sehingga semua dianggap

Gambar 2 Titik pelaksanaan Agility T-Test (Widiastuti, 2011)

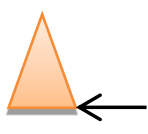

C
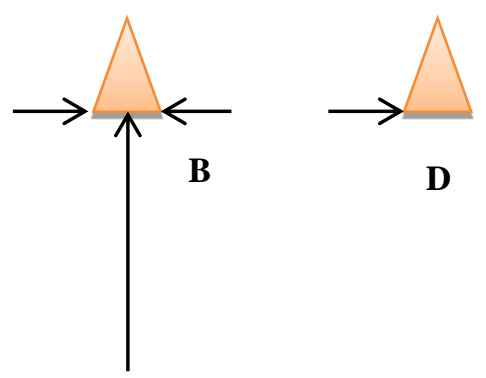

Return board dapat digunakan sebagai sarana untuk mengukur kemampuan forehand topspin seorang atlet. Tes dalam penelitian ini dilakukan dengan pelaksanaan pukulan forehand topspin dengan 3 kali kesempatan, dengan penempatan return board yang paling sama. Penelitian ini dilakukan pada tahun 2017 di kota Kendari.

Pelaksanaan tes kelincahan dengan menggunakan empat kerucut yang membentuk huruf T. Subjek mulai berlari dari garis start titik A menuju titik B dengan menyentuh tangan kanannya pada kerucut, kemudian berlari menyamping kearah titik $\mathrm{C}$ menyentuh kerucut dengan tangan kiri. Kemudian berlari kearah $\mathrm{D}$ dan menyentuh kerucutnya dengan tangan kanan lalu kembali ketitik B dan terakhir menuju garis finis titik A posisi berlari lurus. Penilaian waktu dimulai ketika mulai berlari dari titik start (kerucut A) sampai dengan kembali ketitik finis (kerucut A). Hasilnya adalah waktu tercepat dari dua kali percobaan. Skor diangap tidak di hitung apabila tidak menyentuh dasar kerucut, atau terseret. Tes kelincahan dengan menggunakan Agility T-Test dapat di lihat pada gambar beserta table acuan penilainnya berikut:
A

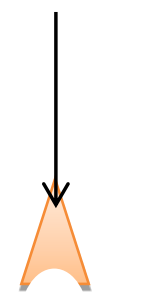


Tabel 1 Nilai Agility T-Test olahraga tim dewasa (Widiastuti, 2011)

\begin{tabular}{|lll|}
\hline & Males (seconds) & Females (seconds) \\
\hline Excellent & $<9.5$ & $<10.5$ \\
Good & 9.5 to 10.5 & 10.5 to 11.5 \\
Average & 10.5 to 11.5 & 11.5 to 12.5 \\
Poor & $>11.5$ & $>12.5$ \\
\hline
\end{tabular}

Pelaksanaan topspin yaitu atlet posisi siap di depan meja, kemudian melakukan pukulan topspin ke papan pantul dengan diberikan 3 kali kesempatan. Cara menilai yaitu dengan mengambil waktu tersingkat dari

Gambar 1. Return board tes forehand topspin (Santosa, 2016)

\section{HASIL DAN PEMBAHASAN}

\section{Hasil}

Instrumen yang telah digunakan dalam penelitian ini untuk mengukur forehand topspin yaitu return board. Adapun hasil dari
3 kali kesempatan melakukan pukulan topspin dengan ketentuan dalam 1 kesempatan mampu melakukan topspin sebanyak 3 pukulan masuk secara berturut.

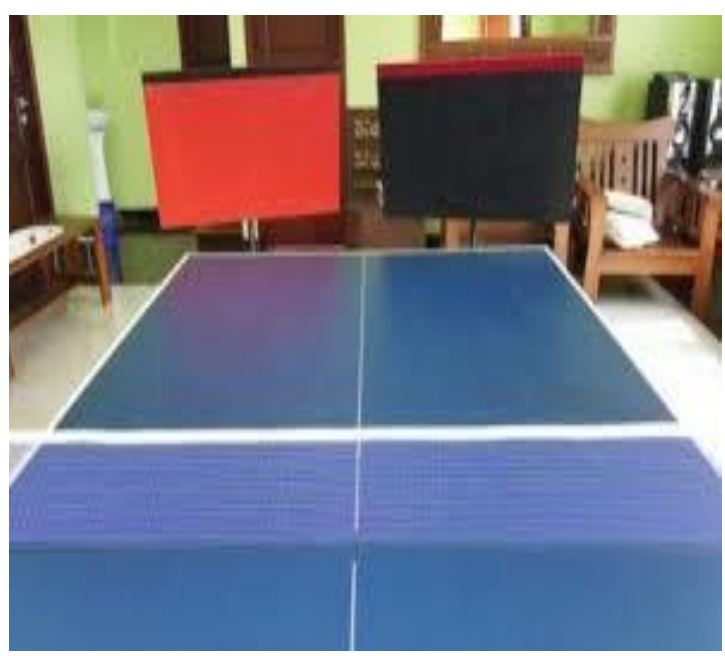

Tabel 2 Deskripsi statistik forehand topspin.

\begin{tabular}{cccccc}
\hline & \multicolumn{5}{c}{ N Minimum Maximum Mean Std. Deviation } \\
\cline { 2 - 6 } Topspin & 36 & .19 & .72 & .4481 & .16952 \\
Valid N (listwise) & 36 & & & & \\
\hline
\end{tabular}

Apabila hasil deskripsi di atas

penilaian terlihat pada ilustrasi tabel berikut: Berdasarkan hasil tabel 2 maka diperoleh nilai rata-rata 0.4481 dengan standar deviasi 0.16952 sedangkan skor tertinggi sebesar 0.72 dan skor terendanya sebesar 0.19 . disesuaikan berdasarkan kriteria pukulan

forehand topspin pada atlet putra penilaiannya

Tabel 3 Deskripsi statistik forehand topspin.

\begin{tabular}{ccccc}
\hline Kriteria & Pria (detik) & Wanita (detik) & Frekuensi & Persentase (\%) \\
\hline Sangat Tinggi & $<0,20$ & $<0,25$ & 5 & 13,9 \\
Tinggi & $0,21-0,40$ & $0,26-0,45$ & 12 & 33,3 \\
Sedang & $0,41-0,60$ & $0,46-0,65$ & 11 & 30,6 \\
Rendah & $0,61-0,80$ & $0,66-0,85$ & 8 & 22,2 \\
\hline
\end{tabular}




\begin{tabular}{ccccc}
\hline Sangat rendah & $0,81>$ & $0,86>$ & 0 & 0 \\
& Total & & 36 & 100 \\
\hline
\end{tabular}

Berdasarkan tabel 3 diperoleh nilai terbanyak yaitu $0,21-0,40$ terdapat 12 atlet $(33,3 \%)$ memiliki kriteria kemampuan tinggi, sedangkan porolehan nilai terbanyak kedua yaitu 0,41-0,60 sebanyak 11 atlet $(30,6 \%)$ dengan memiliki kriteria kemampuan sedang. Nilai terbanyak ketiga berikutnya berada pada 0,61-0.80 sebanyak 8 atlet $(22,2 \%)$ dengan kriteria kemampuan rendah serta nilai $<0,20$ terdapat 5 orang atlet $(13,9 \%)$ dengan kriteria sangat tinggi.

Instrumen yang digunakan untuk mengukur kelincahan yaitu Agility T-Test, seberapa cepat waktu gerak seorang atlet saat mengubah arah dalam melakukan pukulan serangan forehand topspin. Berikut ini deskripsi hasil uji statistik kelincahan:

Tabel 4 Deskripsi statistik kelincahan

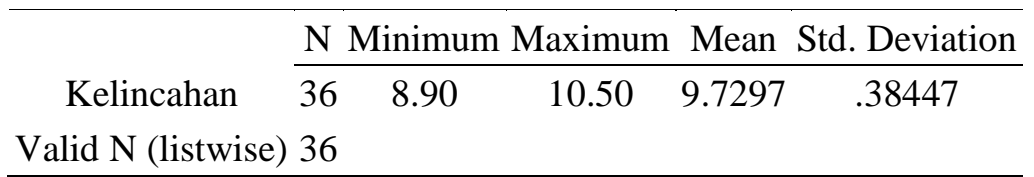

Berdasarkan tabel 4 hasil yang diperoleh rata-rata sebesar 9.7297 dengan standar deviasi 0.38447 dan skor tertinggi sebesar
10.50 serta skor terendahnya sebesar 8.90. Untuk lebih jelasnya hasil deskripsi kelincahan dapat dilihat pada tabel berikut:

Tabel 5 Hasil deskripsi kelincahan

\begin{tabular}{ccccc}
\hline & Males (seconds) & Females (seconds) & frekuensi & Presentase (\%) \\
\cline { 2 - 5 } Excellent & $<9.5$ & $<10.5$ & 7 & 19.4 \\
Good & 9.5 to 10.5 & 10.5 to 11.5 & 24 & 66.7 \\
Average & 10.5 to 11.5 & 11.5 to 12.5 & 5 & 13.9 \\
Poor & $>11.5$ & $>12.5$ & 0 & 0 \\
& Total & & 36 & 100 \\
\hline
\end{tabular}

Berdasarkan tabel 5 dapat dilihat bahwa perolehan nilai terbanyak yaitu 9.5-10.5 terdapat 24 orang atlet $(66.7 \%)$ dengan kriteria baik (good), sedangkan terbanyak kedua berada pada $<9.5$ terdapat 7 atlet $(19.4 \%)$ memiliki kriteria sempurna (excellent). Kemudian pada tingkatan ketiga terbanyak yaitu 10.5-11.5 terdapat 5 orang atlet (13.9\%) dengan kriteria sedang (average).

Tabel 6 Ujikorelasi product moment
Kriteria pengujian hasil penelitian ini, jika nilai $r_{\text {hitung }}>r_{\text {tabel }}$ dengan sig. (2-tailed) lebih kecil dari 0,05 maka dapat dipastikan bahwa ada hubungan yang signifikan antara kelincahan dengan forehand topspin dan apabila nilai $r_{\text {hitung }}>r_{\text {tabel }}$ dengan sig. $(2$ tailed $)$ lebih besar dari 0,05 maka dapat dipastikan tidak ada hubungan yang signifikan. Berikut ini tabel data hasil product moment:

\begin{tabular}{cccc}
\hline & & Kelincahan & Topspin \\
& Pearson Correlation & 1 & $.683^{* *}$ \\
Kelincahan & Sig. (2-tailed) & & .000 \\
& $\mathrm{~N}$ & 36 & 36 \\
\multirow{2}{*}{ topspin } & Pearson Correlation & $.683^{* *}$ & 1 \\
\hline
\end{tabular}




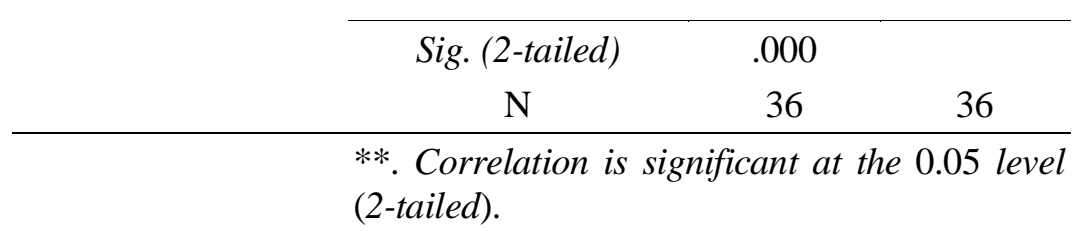

Berdasarkan analisis data pada tabel di atas bahwa sampel 36 (taraf sig. 5\%) diperoleh nilai $r_{\text {tabel }}$ sebesar $=0,329$ sedangkan dari hasil uji $r_{\text {hitung }}$ diperoleh nilai sebesar 0,683 dengan sig. (2 tailed) 0,000 artinya $t_{\text {hitung }}>t_{\text {tabel }}$ dengan sig. $(2$ tailed $)<0,05$ maka $\mathrm{H}_{0}$ ditolak. Penilaian penelitian ini dapat ditafsirkan bahwa terdapat hubungan yang signifikan antara kelincahan dengan forehand topspin tenis meja atlet kota Kendari yang memiliki kriteria kuat.

\section{Pembahasan}

Penelitian sebelumnya telah mengungkapkan faktor-faktor yang mempengaruhi kemampuan forehand tospspin. Namun, masih banyak yang belum terjawab seperti kelincahan, motivasi, koordinasi matatangan, kecepatan, mental dan gizi. Olehnya itu diperlukan suatu penelitian untuk menjawab semua masalah-masalah yang ditemukan saat melakukan pengamatan terhadap pelaksanaan teknik topspin. Dalam peneltian ini menggunakan unsur kelincahan untuk memastikan kontribusinya terhadap topspin. Kemudian mengukur seberapa besar korelasi yang dimiliki oleh kelincahan dengan peningkatan topspin tenis meja. Sehingga dapat dijadikan sebagai dasar perhatian dalam penyusunan program latihan atlet.

Hasil uji analisis antara kelincahan dengan forehand topspin pada atlet putra tenis meja kota Kendari disimpulkan memiliki korelasi kuat. Hal ini sejalan tentang adanya korelasi antara kelincahan terhadap keterampilan smash kedeng (Siswanto, Rahayu, \& Fakhruddin, 2017). Pendapat lain mengemukakan bahwa terdapat korelasi signifikan pada kelincahan dengan keterampilan bermain tenis meja (Syamsuddin, 2012). Sehingga dapat dipastikan terdapat hubungan kuat antara kelincahan dalam meningkatkan forehand topspin atlet putra tenis meja kota Kendari.

Faktor kelincahan dapat dijadikan sebagai salah satu dasar untuk meningkatkan topspin, dan dapat dimanfaatkan bagi setiap pelatih untuk memacu kemampuan setiap atlet yang dibina pada cabang tenis meja. Variabel kelincahan memiliki korelasi signifikan secara mutlak pada keterampilan menggiring bola basket (Fajar Hidayatullah, 2018). Dengan demikian semakin rendah penguasaan kelincahan seorang atlet, maka semakin rendah pula kualitas penguasaan teknik permainan khususnya kemampuan forehand topspin. Dipertegas pendapat lain bahwa selain program latihan yang sangat bagus juga harus memiliki kondisi fisik yaitu kelincahan yang bagus (Akbar, 2015). Sehingga dapat dipastikan unsur kelincahan menjadi salah satu unsur penentu dalam keberhasilan dalam melakukan suatu gerakan terutama pukulan forehand topspin. Oleh karena itu, perlu diperhatikan oleh para pelatih cabang olahraga tenis meja dalam membina atlet kiranya selalu meningkatkan ataupun menjaga kualitas terutama kelincahan yang sangat menentukan keberhasilan pada saat melakukan gerakan forehand topspin permainan tenis meja.

Hasil yang telah di dapatkan dari perhitungan kelincahan atlet putra kota Kendari berada pada kategori baik sehingga memiliki efek peningkatan dalam melakukan pergerakan topspin. Berdasarkan data penelitian ini bahwa terdapat 12 orang atlet memperoleh kriteria tinggi sebesar $(33,3 \%)$ pada kemampuan pukulan topspin, sehingga besar kemungkinan untuk ditingkatkan pada level berikutnya. Kemudian terdapat 11 orang atlet mempunyai kriteria sedang pada kemampuan pukulan topspin sebesar $(30,6 \%)$ dan terdapat 8 orang atlet masih memiliki kriteria rendah sebesar $(22,2 \%)$. Jadi, untuk mamacu peningkatan kemampuan pukulan 
topspin atlet dapat diperhatikan melalui peningkatan kelincahan seorang atlet. Semakin lincah pergerakan seorang atlet maka semakin baik pula kualitas kemampuan pukulan topspin. Selanjutnya terdapat 5 atlet dengan kriteria sangat tinggi sebesar $(13,9 \%)$ atas kemampuan topspin, karena hal tersebut dikorelasi antara dari kualitas kelincahan yang baik dan sempurna sehingga memperoleh hasil yang tinggi. Hal ini menunjukan peran penting topspin pada presentase tinggi dalam pencapaian kesuksesan setiap game. Sehingga topspin ini dikategorikan teknik yang penting untuk dikuasai oleh setiap atlet. Ketika melakukan topspin mengayun ke depan (forward swing) pada posisi memutar beban badan ke tumpuan kaki kiri (Groß \& Schlager, 2011).

Demikian memiliki kelincahan yang cukup dapat meningkatkan topspin seseorang pada setiap gerakan pukulan serangan yang dilakukan, sebaliknya jika kelincahan seseorang tidak baik maka topspin seorang atlet akan mengalami kegagalan terutama pada bola yang berada jauh dari jangkauan. Seperti penelitian berikut mengungkapkan terdapat korelasi yang kuat pada kelincahan dengan keterampilan menggiring (Sari, 2019). Kemudian ada hubungan yang tinggi antara kelincahan pada keterampilan tenis meja (Saleh, 2012). Diperkuat penelitian lain memperlihatkan hasil korelasi yang tinggi antara kelincahan dengan keterampilan tenis meja (Syamsuddin, 2012). Berdasarkan pendapat dia atas dipastikan bahwa pemain yang memiliki tingkat kelincahan yang cukup bahkan dengan nilai sempurna, memudahkan pergerakan merubah sasaran dengan keadaan berpindah tempat melalui percepatan gerak khususnya ketika melakukan gerakan topspin. Terutama pada kondisi bola yang datang berada pada posisi jauh dari jangkauan.

Kelincahan adalah komponen motorik tentang pergerakan tubuh secara cepat dan tepat tanpa kehilangan keseimbangan. Sehingga memberi peluang untuk bertindak sesuai arah saling berlawanan. Kelincahan menentukan keberhasilan kecepatan melakukan pukulan topspin keberbagai arah permukaan meja.

Hasil penelitian ini mengungkapakan adanya korelasi kuat antara kelincahan dengan peningkatan forehand topspin atlet putra tenis meja kota Kendari. Dengan memperhatikan kelincahan seorang atlet maka akan dapat meningkatkan ataupun menjaga kualitas topspin yang dimiliki seorang talet. Namun faktor kelincahan sangat dipengaruhi oleh faktor gender dan umur. Dengan bertambahnya umur individu, maka bertambah menurun kelincahan yang dimiliki. Kelincahan berkorelasi signifikan dengan usia pada permainan tenis meja (Horníková, Doležajová, \& Zemková, 2018). Namun kekurangannya kelincahan jika digunakan lebih berefek pada subjek yang berusia muda dibandingkan usia tua, sehingga ketika diterapkan pada usia tua, akan menyebabkan kesalahan pukulan dalam bermain tenis meja.

\section{SIMPULAN}

Kelincahan memiliki hubungan yang erat pada peningkatan kemampuan topspin tenis meja atlet kota Kendari. Hasil penelitian ini bukan satu-satunya akan tetapi dapat digunakan sebagai dasar untuk mengembangkan penelitian lain yang mempunyai permasalahan atau kondisi mirip dengan model penelitian ini. Pada setiap pergerakan olahraga prestasi banyak faktor yang berperan penting, misalnya faktor latihan, atlet, pelatih, dan lingkungan. Sehingga kenyataannya setiap atlet memiliki kemapuan yang berbeda dalam tingkatan untuk berhasil dalam mempelajari keterampilan gerak tertentu terutama dalam permainan tenis meja.

\section{UCAPAN TERIMAKASIH}

Penulisan artikel ini dapat terselesaikan tentunya berkat bantuan dari berbagai pihak, untuk itu dengan segala kerendahan hati penulis mengucapkan terimakasih kepada seluruh civitas akademika USN Kolaka telah memberikan 
dukungan, bantuan dan motivasi pada penulis dari awal hingga penyelesaian artikel ini. Pada kesempatan ini penulis menyampaikan terimakasih pada seluruh keluarga, kerabat telah menjadi matahari penyemangat dalam menyelesaikan artikel.

Mudah-mudahan artikel ini bermanfaat bagi pembaca serta pengembangan penelitian lainnya terkait kasus yang sesuai dengan tema ini. Semoga Allah SWT memberikan balasan yang terbaik. Amiiinn.

\section{DAFTAR PUSTAKA}

Akbar, A. (2015). Evaluasi unsur kelincahan dan kecepatan reaksi otot tangan atlet tarung derajat binaan satlat unsyiah tahun 2013. Jurnal Ilmiah Mahasiswa Pendidikan Jasmani, Kesehatan Dan Rekreasi, 1(1).

Fajar Hidayatullah. (2018). Hubungan kelincahan dengan keterampilan menggiring bola basket mahasiswa baru program studi pendidikan olahraga stkip pgri bangkalan. Sport Area, 3(1), 28-35. Retrieved from http://journal.uir.ac.id/index.php/JSP/arti cle/download/1555/1075

Gross \& Schlager. (2011). Table tennis. Maidenhead: Meyer \& Meyer Sport.

Henry, G., Dawson, B., Lay, B., \& Young, W. (2012). Effects of a feint on reactive agility performance. Journal of Sports Sciences, $\quad 30(8), \quad 787-795$. https://doi.org/10.1080/02640414.2012.6 71527

Horníková, H., Doležajová, L., \& Zemková, E. (2018). Playing table tennis contributes to better agility performance in middle-aged and older subjects. Acta Gymnica, 48(1), 15-20. https://doi.org/10.5507/ag.2018.004

Liefeith, A., Kiely, J., Collins, D., \& Richards, J. (2018). Back to the Futurein support of a renewed emphasis on generic agility training within sports- specific developmental pathways. Journal of Sports Sciences, 36(19), 2250-2255.

https://doi.org/10.1080/02640414.2018.1 449088

Lubis, J. (2013). Panduan praktis penyusunan program latihan (1st ed.). Jakarta: PT Raja Grafindo Persada.

Mylsidayu, A., \& Kurniawan, F. (2015). Ilmu Kepelatihan Dasar. Bandung: Alfabeta.

Paul, D. J., Gabbett, T. J., \& Nassis, G. P. (2016). Agility in Team Sports: Testing, Training and Factors Affecting Performance. Sports Medicine, 46(3), 421-442.

https://doi.org/10.1007/s40279-0150428-2

Rahmani, M. (2014). Buku super lengkap olahraga. Jakarta: Dunia Cerdas Jaya.

Safaringga, E., \& Herpandika, R. P. (2018). Hubungan antara Kebugaran Jasmani dengan Kualitas Tidur. Jurnal SPORTIF: Jurnal Penelitian Pembelajaran, 4(2), 235. https://doi.org/10.29407/js_unpgri.v4i2.1 2467

Saleh, M. S. (2012). Hubungan antara kekuatan lengan, kelincahan, dan kecepatan reaksi tangan dengan kemampuan bermain tenis meja pada siswa smp negeri 23 makassar. Jurnal Pendidikan Kepelatihan Olahraga, 4(2).

Santosa, T. (2016). Pengembangan alat bantu return board untuk forehand topspin tenis teja. Jurnal Pedagogik Olahraga, 2(2), 30-48.

Sari, H. P. (2019). Hubungan kelincahandengan keterampilan dribbling bola pada siswa ekstrakurikuler bola basket smp negeri 16 palembang tahun ajaran 2017/2018. In SEMINAR NASIONAL OLAHRAGA, 1(1). 
Sheppard, J., \& Young, W. (2006). Agility literature review: Classifications, training and testing. Journal of Sports Sciences, 24(9), 919-932. https://doi.org/10.1080/02640410500457 109

Siswanto, Rahayu, T., \& Fakhruddin. (2017). Hubungan Kelincahan, Kelentukan Togok dan Daya Ledak Otot Tungkai terhadap Kemampuan Smash Kedeng Sepaktakraw pada Siswa Ekstrakurikuler SD Negeri Margomulyo Pegandon Kendal. Journal of Physical Education and Sports, 6(1), 88-94.

Sonoda, T., Tashiro, Y., Suzuki, Y., Kajiwara, Y., Zeidan, H., Yokota, Y., ... Aoyama, T. (2018). Relationship between agility and lower limb muscle strength, targeting university badminton players. Journal of Physical Therapy Science, $30(2)$, 320-323 https://doi.org/10.1589/jpts.30.320
Suwo, R. (2019). Pengaruh kecepatan reaksi tangan terhadap kemampuan forehand topspin (Path analysis pada atlet tenis meja UNSIKA karawang 2016). Riyadhoh: Jurnal Pendidikan Olahraga, 1(1), 21-25.

Syamsuddin, N. (2012). Hubungan antara kekuatan lengan, kelincahan, dan kecepatan reaksi tangan dengan kemampuan bermain tenis meja pada siswa sma negeri sungguminasa. Jurnal Pendidikan Kepelatihan, 4(3).

Widiastuti. (2011). Tes dan Pengukuran Olahraga. Jakarta: PT Bumi Timur Jaya.

Zagatto, A. M., Kondric, M., Knechtle, B., Nikolaidis, P. T., \& Sperlich, B. (2018). Energetic demand and physical conditioning of table tennis players. A study review. Journal of Sports Sciences, 36(7), 724-731. https://doi.org/10.1080/02640414.2017.1 335957 